\title{
Analysis and Comparison of Securitization Cases About Tourist Attractions
}

\author{
Chen Huang ${ }^{1, *}$ \\ ${ }^{1}$ Shanghai University, Nantong, Jiangsu Province, China \\ ${ }^{*}$ Corresponding author. Email:798055366@qq.com

\section{ABSTRACT} \\ With the rise of tourism, China, as a country famous for its tourism, has attracted more and more attention on \\ financing. Starting with securitization of assets, this paper collects securitization cases about tourist attractions. \\ Through analysis and comparison of various cases, it finds out the financing difficulties of tourism industry. For a fine \\ future, we need to develop securitization about tourist attractions.
}

Keywords: Tourism, Securitization of assets, Financing.

\section{旅游景区资产证券化案例分析及对比}

\section{黄晨 $1,^{*}$}

1 上海大学，江苏南通，中国

“通讯作者. 邮箱: 798055366@qq. com

\section{中文摘要}

随着旅游业的兴起，中国作为一个旅游大国，越来越多地关注起融资问题。本文从资产证券化入手，搜集了旅 游景区的资产证券化案例, 通过各种案例的比较分析, 发现旅游业融资难的问题, 并对未来提出展望, 进一步 发展旅游景区资产证券化。

关键词：旅游业；资产证券化；融资

\section{1. 绪论}

中国一直是旅游消费大国。从2014-2019年来, 国 内旅游收入的增长率一直很高, 达到了 $10 \%$, 国内旅 游收入占全国旅游收入的比重也很高, 占到了 $80 \%$ 以 上。

中国的旅游业发展值得期待的原因有四。首先是 中国幅员辽阔，人口众多，四时景色各不相同，人们 愿意去欣赏祖国的大好河山; 第二是, 中国近年来, 交通发展极其迅速，得益于党的领导，铁路、公路、 航空三线并进, 二三线城市的地铁也在进一步完善, 且更交通部门的服务设施也更为舒适便捷。出行时间
缩短, 旅途更为舒适, 人们在节假日出去旅游的意愿 就更为强烈; 其次是, 各景区的文化保护工作做的越 来越出色, 更多有文化底蕴的景点值得去游览; 最后 一点是国民经济的发展好，人们的文化生活更为丰 富，更愿意花钱在旅游等促进精神文化发展的领域。

本文主要从资产证券化的角度，来介绍认识旅游 景区业务。景区发行的证券化产品中，有一些资产证 券化的案例可供分析，其中，比较特殊的是最新一期 的平遥古城证券化, 主承是信托公司, 是一个很好的 创新形式。 


\section{2. 文献综述}

中国旅游业ABS发展缓慢, 所以目前我国对旅游 行业的资产证券化研究较少。相关研究中, 张奇(2014) 从理论上系统地分析了旅游业资产证券化的概念和 过程, 并且运用相关理论讲解了旅游业的基础资产。 周南洋(2004)提出了提出了一个设想, 希望借由资产 证券化，促进西部旅游业融资。

其余文献中有研究旅游证券化的实际运用, 张国 胜和叶瑶云 (2008) 以八达岭长城资产支持证券项目为 例, 论证了两种 $\mathrm{ABS}$ 的模式, 并进一步设想了具体的 操作流程和政策建议。范定祥和何艳(2009)认为要使 得旅游公司资金充裕、证券化实现, 依赖于景区经营 权、土司所有权和使用权的流转交易, 并就此进行了 实证验证。
对于我国旅游业资产证券化发展存在的问题，刘 芗(2006)提出可以运用资产证券化和期权合约等金融 创新手段, 解决如今旅游业融资难的困难。

\section{3. 旅游景区资产证券化概述}

\section{如图1所示}

（1）由计划管理人发起设立专项计划; 划内;

（2）由原始权益人将相关基础资产装入到专项计

（3）由评级机构、律师事务所、会计师事务对发 行主体、债项进行评级，出具相关法律文件及财务审 计报告;

（4）由担保方提供增信措施;

（5）向交易所申请挂牌交易;

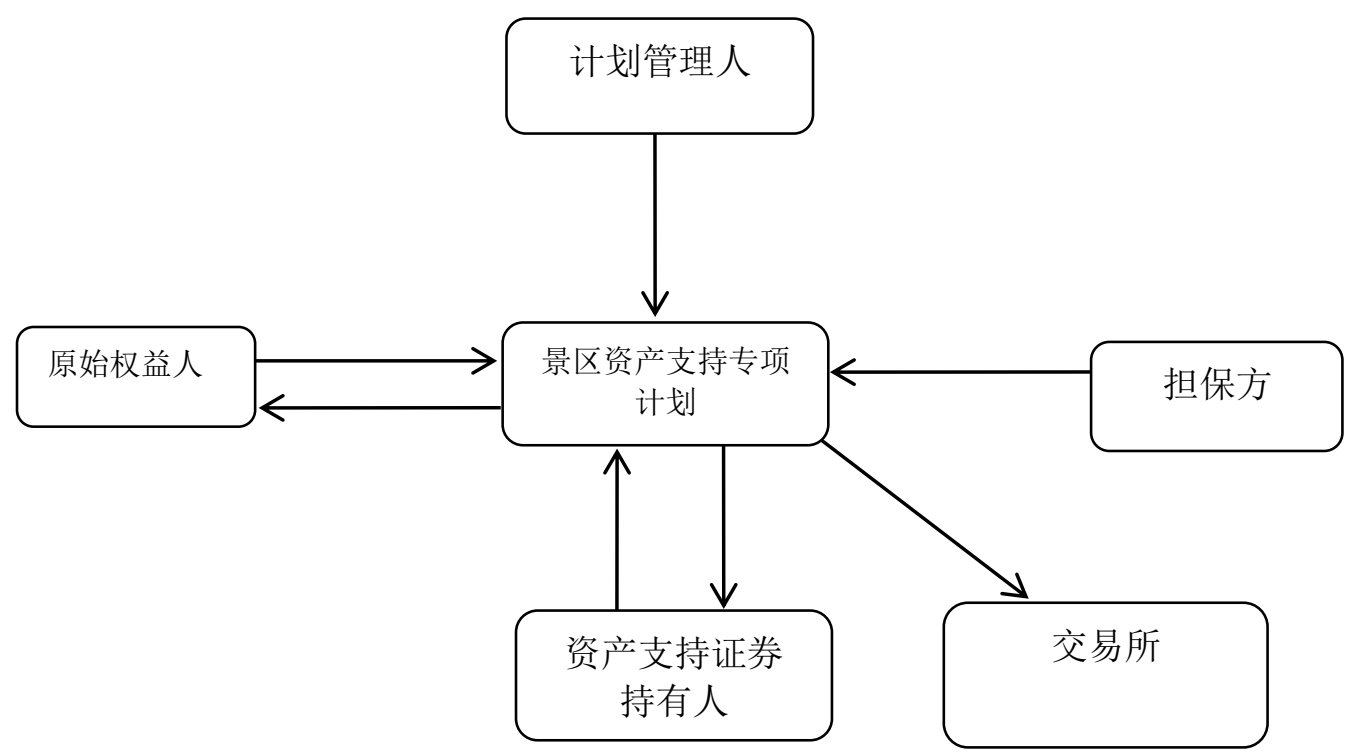

图1 资产证券化流程图

\section{4. 案例分析以及对比}

本章节主要搜集了2017年发行的几个资产支持证 券案例, 从两个方面详细地对比分析, 以华山景区服 务费资产支持专项计划作为基础对比对象。

\section{1. 基础资产类型总体对比}

由表 1 可以看出, 总体上, 我国的ABS发型数额巨 大，且种类庞多。其中，以个人消费贷款发行数量最 多, 且发行金额最大。以股票质押回购发行数量、种 类最小。

而收费收益权的比重相对来说，也是占比较小。 这表明, 旅游收益资产证券化的规模还很小, 发展中 存在困难, 但未来发展空间巨大。旅游收益资产证券 化在试点初期, 规模很小, 融资有限, 。第一个收益 权证券化是在2012年, 发展缓慢。虽然说, 中国是一
个旅游大国, 但在旅游收益资产证券化上要做的依然 很多。

\section{2. 四个项目各要素具体对比}

在这里选取2016年、2017年发行的3个公园景区收 益权类的资产支持证券和 1 个总类规模最大的个人消 费贷款作对比，四个项目的各要素数值如下表 2 所示。

首先从发行规模看, 在三个旅游景区收益权产品 的同类对比中，曼听公园及巴拉格宗的发行规模较 大，华山景区服务费资产支持专项计划的最小。因为 华山景区的资金比较充裕, 融资需求小。中金花呗是 个人消费贷款类产品，基础资产市场规模大，回收期 限较短, 因而预计期限短, 融资规模却极大。从以上 数据分析不难看出, 相较于个人消费贷, 旅游业证券 化产品的发行仍存在着许多困难。 
从发行的预计期限角度进行比较, 所有产品中, 巴拉格宗和曼听公园两个产品预计期限较长, 因为是 较冷门的景区, 所以市场认可度不高, 票面利率低, 预计期限长。中金花呗很受投资者青睐, 所以它的预 计期限短。

再从发行利率分析，华山景区服务费资产支持专 项计划的发行利率处于一个中间数值, 说明相对巴拉 格宗而言, 华山景区的原始权益人的融资成本要更 低。因为华山景区是知名度很高的景区，游客多，收
益高，融资更容易。但小微旅游企业资产证券化就相 当困难, 例如曼听公园市场认可度不高, 管理存在漏 洞, 最近就有清算问题。

在发行规模、预计期限、发行利率三方面进行细 致的比较分析以后, 我们得出结论, 华山景区服务费 资产支持专项计划的市场认可度很高，而中金花呗由 于其现金流规模庞大，回收期限短，也容易获得更多 的投资。

表1２017年资产支持证券发行情况

\begin{tabular}{c|c|c}
\hline 产品分类 & 发行总数 & 发行总额（亿） \\
\hline 企业贷款 & 29 & 1204.83 \\
\hline 汽车抵押贷款 & 31 & 1089.78 \\
\hline 住房抵押贷款 & 19 & 1707.51 \\
\hline 不良资产重组 & 19 & 129.61 \\
\hline 金融租赁 & 11 & 345.67 \\
\hline 小额贷款 & 26 & 241.94 \\
\hline 融资租赁 & 72 & 816.07 \\
\hline 收费收益权 & 34 & 284.9 \\
\hline 个人消费贷款 & 123 & 2864.66 \\
\hline 应收账款 & 56 & 692.9 \\
\hline 委托贷款 & 7 & 86.89 \\
\hline BEITs & 14 & 266.34 \\
\hline 保理融资 & 65 & 591.91 \\
\hline 信托受益权 & 56 & 1514.44 \\
\hline 两融债权 & 8 & 24.46 \\
\hline 股票质押回购 & 3 & \\
\hline & &
\end{tabular}

表 2 四个项目的基本要素

\begin{tabular}{|l|l|l|l|l|}
\hline 项目名称 & $\begin{array}{l}\text { 云南文产巴拉格 } \\
\text { 宗入园凭证资产 } \\
\text { 支持专项计划 } \\
\text { 持专项计划 }\end{array}$ & $\begin{array}{l}\text { 资产支 } \\
\text { 农银穗盈-建投汇 } \\
\text { 景-华山景区服务 } \\
\text { 费资产支持专项 } \\
\text { 计划 }\end{array}$ & $\begin{array}{l}\text { 唝 消费授 } \\
\text { 资资资产支诗 }\end{array}$ \\
\hline 金额 & 8.4 亿 & & \\
\hline 发行利率 & $6.00 \%-7.35 \%$ & 3.7 亿 & 2.12 亿 & 25 亿 \\
\hline 基础资产 & 入园凭证 & 演出门票 & 劳务服务费 & 个人信用贷债权 \\
\hline 期限 & 7 年 & 7.64 年 & 3.44 年 & 1 年 \\
\hline 发行方式 & $\begin{array}{l}\text { 私募 不超过 } 200 \\
\text { 合格投资者 }\end{array}$ & $\begin{array}{l}\text { 私募 不超过 } 200 \\
\text { 合格投资者 }\end{array}$ & $\begin{array}{l}\text { 私募 不超过 } 200 \\
\text { 合格投资者 }\end{array}$ & $\begin{array}{l}\text { 私募 不超过 } \\
\text { 合格投资者 }\end{array}$ \\
\hline 产品状态 & 存续期 & 提前清算 & 存续期 & 存续期 \\
\hline 评级 & AA+ & AAA & AAA & AAA \\
\hline
\end{tabular}

\section{5. 结论与展望}

在所有的发展中的旅游企业中, 可分为资金充足 的大、中型旅游企业和资金周转差的小企业。一般情
况下, 我国的小型企业发展都会受到资金的限制，在 旅游资源上尤其如此。 
小型旅游企业发展的车难点在于融资难, 融资难 的原因在于部分景区不是很出名, 游客量少, 门票等 收入低, 进一步导致资金缺乏, 公司资金周转困难, 本身营运艰难, 更无法进行景点维护和改善, 所以进 一步恶化了我国旅游业的发展。此时, 资产证券化就 显得尤为重要。

旅游景区资产证券化产品是一个创新模式的融资 尝试, 缓解了景区资金紧张的问题。旅游产业本身就 在转型的初步阶段, 有问题应当去解决问题, 迎难而 上。将旅游景区的门票收益等的资产证券化, 不仅符 合国家旅游政策导向, 也有助于旅游业利用资本市场 支持获得充足的资金，实现中长期战略性发展。

\section{REFERENCES}

[1] Ying Liu. Expansion of Tourism Financing Methods [J]. Special Zone Economy, 2006(6):221-222

[2] Lei Zhang, Liang Chen. Discussion on the Multiple Models of Tourism Asset Securitization -- A Case Study of Guilin Tourism [J]. Special Zone Economy, 2011(7):149-151

[3] Chaoying Zhang. Theoretical Analysis on the Motivation of Asset Securitization [J]. Finance and Trade Economics, 2003 (6).

[4] Nanyang Zhou. Traction of Western Tourism by Asset Securitization [J]. Enterprise Reform and Management, 2004(6): 33-35 5

[5] Dingxiang Fan, Yan He. Financing of Scenic Spot Development Based on Tourism Resource Capitalization $[\mathrm{J}]$. Economic Forum 2009(3):102-103

[6] Guosheng Zhang, Yaoyun Ye. Tourism asset securitization model exploration [J]. Management Observation, 2008(22).

[7] Qi Zhang. Innovative Direction of Investment and Financing Mode of Tourist Attractions: Asset Securitization [N]. China Tourism News 2014(7) 